\title{
Negative lon Fragmentation of Cysteic Acid Containing Peptides: Cysteic Acid as a Fixed Negative Charge
}

\author{
Brad J. Williams, Christopher K. Barlow, Kevin L. Kmiec, William K. Russell, \\ David H. Russell
}

Department of Chemistry, Texas A\&M University, College Station, TX 77843, USA

\begin{abstract}
We present here a study of the collision induced dissociation (CID) of deprotonated cysteic acid containing peptides produced by MALDI. The effect of cysteic acid $\left(\mathrm{C}_{\mathrm{ox}}\right)$ position is interrogated by considering the positional isomers, $\mathrm{C}_{\mathrm{ox}}$ LVINVLSQG, LVINVLSQGC $_{\mathrm{ox}}$, and LVINVC $_{\mathrm{ox}} \mathrm{LSQG}_{\text {. }}$ Although considerable variation between the CID spectra is observed, the mechanistic picture that emerges involves charge retention at the deprotonated cysteic acid side chain. Fragmentation occurs in the proximity of the cysteic acid group by charge directed mechanisms as well as remote from this group to form ions, which may be rationalized by charge remote mechanisms. Additionally, the formation of the $\mathrm{SO}_{3}{ }^{-}$ion is observed in all cases. Fragmentation of $\mathrm{C}_{\mathrm{ox}}$ LVINVLSQC $\mathrm{ox}_{\text {ox }}$ provides both $\mathrm{N}$ - and $\mathrm{C}$-terminal, $\mathrm{y}$ and $\mathrm{b}$ ions, respectively indicating that the negative charge may be retained at either of the cysteic acids; however, there is some evidence that charge retention at the C-terminal cysteic acid may be preferred. Fragmentation of tryptic type peptides containing a C-terminal arginine or lysine residue is considered through comparison of three peptides $C_{\text {ox }}$ LVINKLSQG, $C_{o x}$ LVINVLSQK, and $C_{o x}$ LVINVLSQR. Lastly, we rationalize the formation of $\mathrm{b}_{n-1}+\mathrm{H}_{2} \mathrm{O}$ and $\mathrm{a}_{n-1}$ ions through a mechanism involving rearrangement of the $\mathrm{C}$-terminal residue to form a mixed anhydride intermediate.
\end{abstract}

Key words: Solution-phase performic acid oxidation, Negative ion tandem mass spectrometry, Cysteic acid-containing peptides, d-type fragment ions, MALDI-MS

\section{Introduction}

$\mathrm{O}$ xidative stress resulting from an increase in cellular levels of reactive oxygen species (ROS) is implicated in a diverse array of pathologies, including neurodegenerative disease [1], cancer [2], and diabetes [3]. To prevent indiscriminant and detrimental oxidation, the cell employs a complex system of buffers, the most prominent example of

Electronic supplementary material The online version of this article (doi:10.1007/s13361-011-0165-1) contains supplementary material, which is available to authorized users.

Correspondence to: David H. Russell; e-mail: russell@mail.chem.tamu.edu which is the glutathione disulfide/glutathione redox couple [4], in conjunction with an array of enzymes capable of reversing oxidative modifications. The thiol moiety in cysteine residues is susceptible to a variety of oxidative post-translational modifications driven by the capacity of sulfur to adopt several stable oxidation states [5]. Protein thiols potentially make a substantial contribution to the redox buffering of the cell through reversible oxidation at cysteine residues, the most familiar example of which involves disulfide bond formation [6]. In addition to disulfide bond formation, reaction of cysteine thiolates with hydrogen peroxide, the major ROS in the cell [7], produces cysteine sulfenic acid residues (RSOH). Cysteine sulfenic acid residues have attracted considerable attention recently 
due to their role in signaling pathways involving a wide array of cellular responses including, cell proliferation, apoptosis, differentiation, and migration [8-10]. They are comparatively unstable and may either be reduced to regenerate the thiol, undergo disulfide or sulfonamide formation [11], or undergo further oxidation by reaction with $\mathrm{H}_{2} \mathrm{O}_{2}$ to successively yield cysteine sulfinic $\left(\mathrm{RSO}_{2} \mathrm{H}\right)$ and cysteic acid ${ }^{1}\left(\mathrm{RSO}_{3} \mathrm{H}\right)$ residues. It has been estimated that up to $5 \%$ of cellular protein cysteine residues occur in the sulfinic or cysteic acid form [12]. Oxidation of cysteine to sulfinic and cysteic acids is typically irreversible, although the recently discovered sulfiredoxin enzyme is able to reduce sulfinic residues in the peroxiredoxin family of proteins [13]. Under conditions in which the concentration of ROS increases sufficiently to overwhelm the redox buffering capacity of the cell, irreversible oxidation of cysteine residues to sulfinic and cysteic acids may occur. Highly oxidized forms of cysteine are therefore potentially important markers of oxidative stress and have been implicated in promoting protein degradation [14].

Mass spectrometry has become the principal tool for the identification of peptides and proteins, and several recent studies have been concerned with the fragmentation behavior of protonated peptides containing oxidized cysteine residues [15-21]. For peptides in which the ionizing protons are sequestered at highly basic arginine side chains effectively fixing the charge, i.e., non-mobile proton conditions, cleavage of the amide bond $\mathrm{C}$-terminal to cysteic acid residues affords abundant $\mathrm{y}, \mathrm{d}$, or $\mathrm{b}-\mathrm{H}_{2} \mathrm{SO}_{4}$ ions [17-19]. Furthermore, in comparison to their cysteine containing peptide counterparts, the energy required to achieve fragmentation was lower for cysteic acid containing peptides, when the ionizing proton was sequestered at the arginine side chain [18]. Zhang and co-workers note that cleavage of the amide bond $\mathrm{C}$-terminal side of cysteine sulfinic acid residues is even more pronounced than for their cysteic acid counterparts $[19,20]$. The facile nature of this fragmentation may reduce sequence coverage as it outcompetes other low energy CID pathways. Vachet and co-workers have demonstrated that electron transfer dissociation is comparatively insensitive to the presence of a cysteine suflinic acid and so provides greater sequence coverage than CID for cysteic acid containing peptides [21].

Considerably less is known about the fragmentation of deprotonated peptide anions containing highly oxidized cysteine residues. Men and Wang undertook a survey of the low energy CID of a series of deprotonated peptides containing two acidic residues, including cysteine sulfinic and cysteic acid derivatives. In general, spectra were dominated by small molecule losses, such as $\mathrm{H}_{2} \mathrm{O}, \mathrm{H}_{2} \mathrm{~S}$

\footnotetext{
${ }^{1}$ Cysteic acid is synonymous with cysteine sulfonic acid. Here we use the term cysteic acid, the term most widely used in the mass spectrometry literature, and utilize the symbol $\mathrm{C}_{\mathrm{ox}}$ as a single letter abbreviation for this residue.
}

from cysteine contacting peptides and $\mathrm{H}_{2} \mathrm{SO}_{2}$ from cysteine sulfinic acid containing peptides. Additionally, preferential cleavage of the amide bond on the $\mathrm{C}$-terminal side of acidic residues are particularly prominent in the case of cysteine sulfinic acid [22]. We recently reported the TOF-TOF CID spectra for peptides containing an N-terminal cysteic acid, finding extensive formation of $\mathrm{d}$ type ions from residues containing a cleavable $\beta-\gamma$ carbon-carbon bond [23]. Here we extend these investigations to several cysteic acid containing peptides in the negative ion mode in the hope of better understanding the influence of this highly acidic residue on the gas-phase fragmentation observed.

\section{Experimental}

\section{Chemicals}

All chemicals were purchased from Sigma-Aldrich (St. Louis, MO, USA) unless otherwise noted. Hydrogen peroxide $(35 \% \mathrm{wt} / \mathrm{wt})$ and formic acid $(99 \% \mathrm{wt} / \mathrm{wt})$ were purchased from Acros Organics (Morris Plains, NJ, USA). HPLC grade acetone and methanol $\left(\mathrm{CH}_{3} \mathrm{OH}\right)$ were purchased from EMD Chemicals Inc. (Gibbstown, NJ, USA). Custom peptides were purchased from the GenScript Corporation (Piscataway, NJ, USA). All experiments were performed with 18-M $\Omega$ water $\left(\mathrm{ddH}_{2} \mathrm{O}\right)$ purified using a water purification unit (Barnstead International, Dubuque, IA, USA).

\section{Sample Preparation for MALDI-MS}

Stock solutions of each model peptide were prepared at $1 \mathrm{mg} \mathrm{mL} L^{-1}$ in an appropriate solution according to the peptide solubility guidelines provided by the manufacturer. Each stock solution was further diluted to 10 $20 \mu \mathrm{M}$ in $\mathrm{dd}_{2} \mathrm{O}$ or $10 \mathrm{mM}$ formic acid. These peptide solutions were mixed 1:1 with $\mathrm{CH}_{3} \mathrm{OH}$ and $1 \mu \mathrm{L}$ was spotted as an overlayer to pre-spotted $\alpha$-cyano-4-hydroxycinnamic acid (CHCA) matrix. CHCA was prepared at $5 \mathrm{mg} \mathrm{mL}^{-1}$ in a 2:3 $\mathrm{ddH}_{2} \mathrm{O}: \mathrm{CH}_{3} \mathrm{OH}$ solution containing $10 \mathrm{mM}$ $\mathrm{NH}_{4} \mathrm{H}_{2} \mathrm{PO}_{4}$ and $1 \mu \mathrm{L}$ was pre-spotted as the underlayer [24].

\section{Solution-Phase Performic Acid Oxidation}

The model peptides containing cysteine residues were oxidized using solution-phase performic acid oxidation as previously described $[25,26]$. Briefly, $50 \mu \mathrm{L}$ of performic acid (1:19 hydrogen peroxide:formic acid) was used to resuspend ca. $0.5 \mathrm{mg}$ of dry peptide then allowed to react at $0{ }^{\circ} \mathrm{C}$ for $2 \mathrm{~h}$. Following oxidation, samples were diluted with $500 \mu \mathrm{L}$ of $\mathrm{ddH}_{2} \mathrm{O}$ and vacuum dried. The oxidized peptides were then resuspended in $\mathrm{ddH}_{2} \mathrm{O}$ and further diluted to $20 \mu \mathrm{M}$ prior to mixing $1: 1$ ( $\mathrm{vol} / \mathrm{vol})$ with $\mathrm{CH}_{3} \mathrm{OH}$ and spotting on the MALDI target as an overlayer. 


\section{Methylation of Peptides}

The methyl esterification of select peptides was performed using a method similar to that previously described by Reid and co-workers [27]. Briefly, a solution of $2 \mathrm{M}$ hydrochloric acid in methanol was prepared by slowly adding acetyl chloride $(80 \mu \mathrm{L})$ to methanol $(500 \mu \mathrm{L})$ followed by stirring for $5 \mathrm{~min}$ at room temperature. The methanolic $\mathrm{HCl}$ solution $(100 \mu \mathrm{L})$ was added to ca. $0.5 \mathrm{mg}$ of peptide and stirred for $2 \mathrm{~h}$ at room temperature. Following the reaction the methylated peptide was vacuumed dried. The dried peptide was then oxidized using the procedures described above or directly resuspended in an appropriate solvent $\left(1 \mathrm{mg} \mathrm{mL}^{-1}\right)$.

\section{MALDI-MS and MALDI-MS/MS}

All MALDI-MS experiments were performed using a model 4700 Proteomics Analyzer MALDI-TOF/TOF (Applied Biosystems, Framingham, MA, USA). The MALDI-MS data were acquired using the reflectron detector in both positive and negative ion modes using 1200 laser shots with external calibration using bradykinin (2-9) (PPGFSPFR) and adrenocorticotropic hormone (18-39) (RPVKVYPNGAENESAEAFPLEF). Positive and negative ion collision-induced dissociation (CID) tandem MS spectra were acquired using $10 \%-20 \%$ greater laser power than for the MS spectra acquisition. CID experiments were performed with $1 \mathrm{kV}$ acceleration energy using air as the collision gas. The resulting spectrum contains fragment ions formed from both post source decay and high energy CID. Similar nomenclature to that developed by Roepstorff and Fohlman [28] and modified by Biemann et al. [29] for protonated peptides was used to describe the side-chain loss fragment ions observed in the negative ion tandem mass spectra. In the current instance, a deprotonated sequence ion is two mass units lighter than its corresponding protonated counterpart.

\section{Results and Discussion}

\section{Cysteic Acid Positional Dependence}

Figure 1a shows the negative ion MS/MS spectrum of the Nterminal cysteic acid peptide, $\mathrm{C}_{\mathrm{ox}}$ LVINVLSQG. The most prominent product ion is the $\mathrm{SO}_{3}{ }^{-}$ion, which we observe from all cysteic acid containing peptides. The abundance of the $\mathrm{SO}_{3}{ }^{-}$ion raises the possibility that it could be used as a diagnostic product ion for identifying cysteic acid containing peptides from a complex mixture. Additionally, the spectrum shows an extensive series of $\mathrm{N}$-terminal ions including a complete series of $d$ ions $\left(d_{2}\right.$ to $\left.d_{9}\right)$, extensive $a, b$, and $c$ type ions and $\mathrm{a}_{7}+\mathrm{H}_{2} \mathrm{O}$ ion. These observations are similar to those made previously for the negative mode fragmentation of the $\mathrm{N}$ terminal cysteic acid Cys-kemptide ( $\mathrm{C}_{\mathrm{ox}}$ LRRASLG) [23]. The retention of charge at the $\mathrm{N}$-terminus points to a model in which the cysteic acid acts primarily as a fixed charge spectator, thus product ion formation is dominated by charge remote processes. Consistent with this hypothesis, the positive fragment ion spectrum of the N-terminal arginine analogue, RLVINVLSQG, in which the positive charge may be reasonably expected to be sequestered at the arginine side chain, is similar in exhibiting abundant $\mathrm{N}$-terminal ions (Figure 1b). Substitution of the $\mathrm{N}$-terminal $\mathrm{C}_{\mathrm{ox}}$ residue for either aspartic or glutamic acid, DLVINVLSQG (Figure 1c) and ELVINVLSQG (Supplementary Material Figure S1), respectively, primarily dissociate to form $\mathrm{y}$, and to a lesser extent $\mathrm{b}$ type ions. In contrast to the cysteic acid containing peptide, the aspartic and glutamic acid containing peptides fragmentation is inconsistent with the charge being exclusively retained at the acidic side chain, presumably due to the lower gas phase acidity of the carboxylic acid compared with the cysteic acid.

Fragmentation of the C-terminal cysteic acid containing

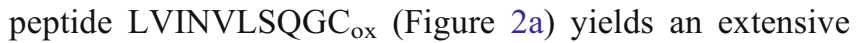
series of C-terminal ions consisting of y $\left(\mathrm{y}_{1}-\mathrm{y}_{9}\right)$ and $\mathrm{w}$ $\left(\mathrm{w}_{3}-\mathrm{w}_{5}, \mathrm{w}_{7}\right.$ and $\left.\mathrm{w}_{8}\right)$ ions. With the exception of the $\mathrm{c}_{3}$ and the $\mathrm{b}_{9}+\mathrm{H}_{2} \mathrm{O}$ ions, no N-terminal fragment ions are observed. These observations suggest that the charge is localized at the cysteic acid. The $\mathrm{b}_{9}+\mathrm{H}_{2} \mathrm{O}$ ion is the second most abundant product ion in the spectrum and corresponds to the elimination of the $\mathrm{C}$-terminal cysteic acid residue, to yield a truncated peptide, $\mathrm{b}_{n-1}+\mathrm{H}_{2} \mathrm{O}$. Cassady and co-workers have previously noted the formation of the $\mathrm{b}_{n-1}+\mathrm{H}_{2} \mathrm{O}$ ions from deprotonated peptides when the $\mathrm{C}$-terminus has either an alcohol (Ser or Thr) or acidic (Asp or Glu) side chain. They proposed a number of mechanisms to account for this product ion $[30,31]$. In the current instance, we suggest a mechanism outlined in Scheme 1 in which the cysteic acid side chain sulfonate acts as a nucleophile towards the adjacent carbonyl carbon to form a cyclic alkoxide intermediate. Ring-opening coupled to proton transfer from the Cterminal carboxylic acid results in the formation of a sulfonic ester. Neighboring group attack at the sulfur by the carboxylate results in the formation of the $\mathrm{b}_{n-1}+\mathrm{H}_{2} \mathrm{O}$ ion.

Figure $2 \mathrm{~b}$ shows the fragment ion spectrum of deprotonated LVINVC ${ }_{\mathrm{ox}} \mathrm{LSQG}$, for which the $\mathrm{C}_{\mathrm{ox}}$ is located in the center of the peptide. The most prominent sequence ion observed is the $\mathrm{y}_{5}$ ion corresponding to cleavage of the amide bond $\mathrm{N}$-terminal side of cysteic acid. Additionally, $\mathrm{w}\left(\mathrm{w}_{6}-\mathrm{w}_{9}\right), \mathrm{v}\left(\mathrm{v}_{6}\right.$ and $\left.\mathrm{v}_{8}\right), \mathrm{d}\left(\mathrm{d}_{7}-\mathrm{d}_{9}\right)$, and the $\mathrm{b}_{7}+\mathrm{H}_{2} \mathrm{O}$ ions are also observed. For all of these ions charge is retained on the cysteic acid containing fragment of the molecule. Indeed, for the three isomeric peptides discussed above, the fragmentation proceeds almost exclusively with retention of charge on the cysteic acid containing fragment ion. This result suggests that cysteic acid sequesters the negative charge independently of its position in the peptide.

The $\mathrm{b}_{7}+\mathrm{H}_{2} \mathrm{O}$ ion observed in the dissociation of $\mathrm{C}_{\text {ox }}$ LVINVLSQG and, to a lesser extent, LVINVC ${ }_{\text {ox }}$ LSQG 
(a)

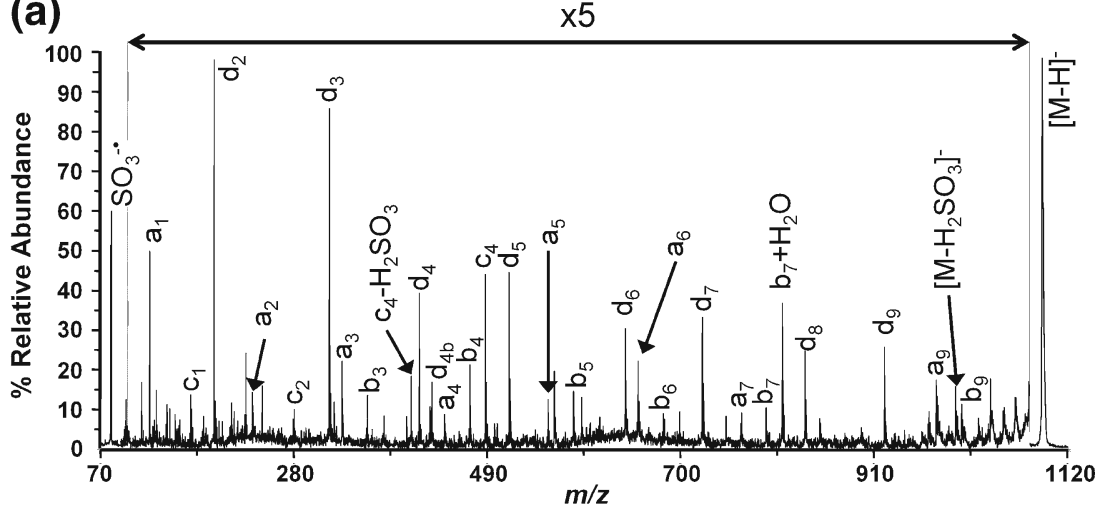

(b)

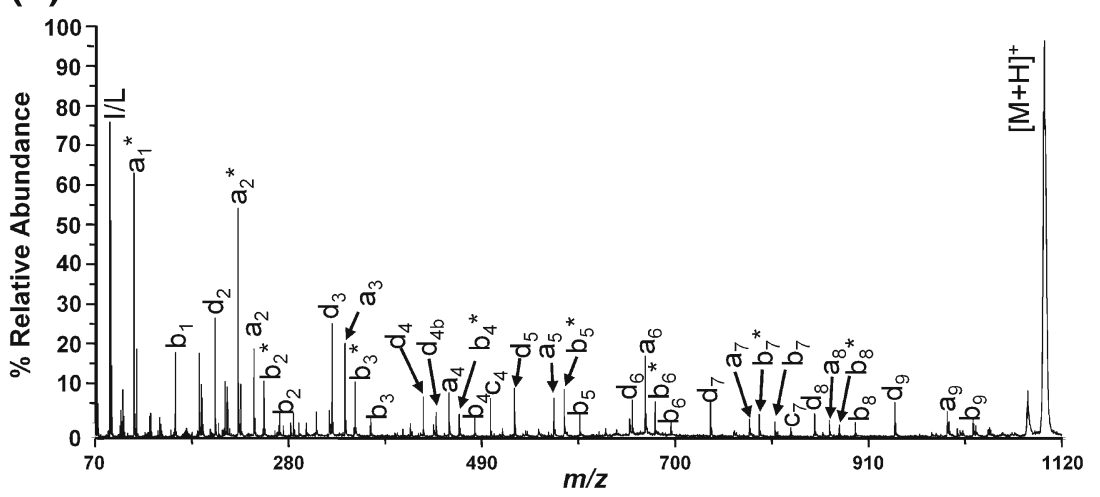

(c)

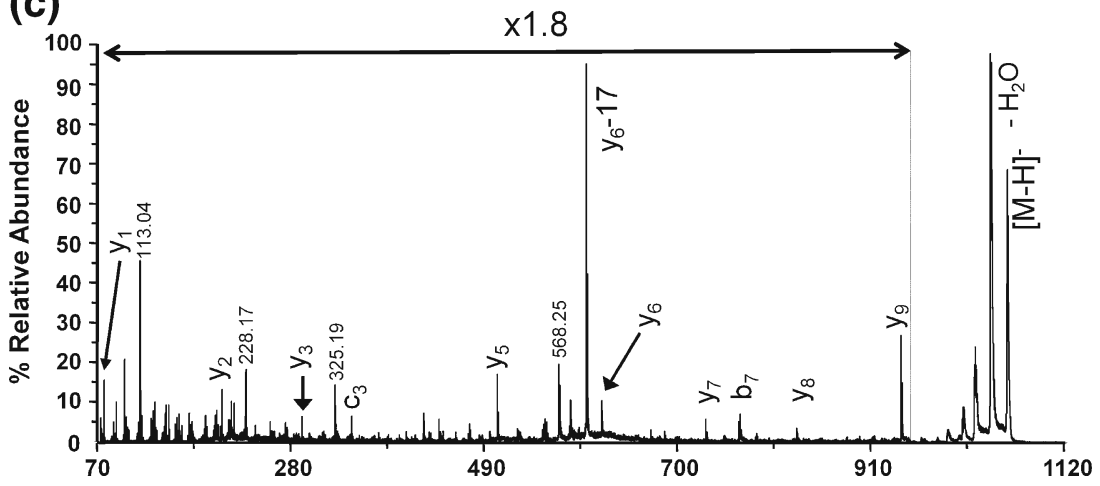

Figure 1. Tandem mass spectra of $[\mathrm{M}-\mathrm{H}]^{-}$ions from (a). $\mathrm{C}_{\mathrm{ox}} \mathrm{LVINVLSQG}$, and (c) DLVINVLSQG, and the $[\mathrm{M}+\mathrm{H}]^{+}$ion of $(\mathbf{b})$ RLVINVLSQG. The * in spectrum (b) indicates the additional loss of $\mathrm{NH}_{3}$

warrants some comment. Fang and co-workers have previously reported the formation of $\mathrm{b}_{i-1}+\mathrm{H}_{2} \mathrm{O}$ ions where the $i$ th residue is a serine or threonine in the positive ion postsource decay spectrum of protonated N-terminal arginine containing peptides [32]. They propose a charge-remote mechanism outlined in Scheme 2. The data here could be rationalized by the same mechanism but in neither case are the mechanistic details proven.

\section{Two Cysteic Acid Groups}

The previous section provides compelling evidence that the cysteic acid residue acts to sequester the negative charge.
Figure 3 shows the TOF-TOF CID spectra of deprotonated $\mathrm{C}_{\mathrm{ox}}$ LVINVLSQC $_{\mathrm{ox}}$, which exhibits both C-terminal y ions $\left(y_{2}-y_{9}\right)$ and N-terminal $b$ ions $\left(b_{5}-b_{9}\right)$. The retention of charge on both the $\mathrm{N}$ - and $\mathrm{C}$-terminal fragments indicates that the negative charge can be located at either of the cysteic acid residues. The most prominent fragment ion corresponds to the neutral loss of $141 \mathrm{Da}$, equivalent to the residue mass of cysteic acid and could therefore be assigned as corresponding to either the $\mathrm{b}_{9}+\mathrm{H}_{2} \mathrm{O}$ or $\mathrm{y}_{9}$ ions. We assign this loss to the $\mathrm{y}_{9}$ ion based on the observation that this peak is also the major product ion in the corresponding methyl ester, in which case we would expect $b_{9}+\mathrm{H}_{2} \mathrm{O}$ ion formation to be blocked, or at least no longer isomeric with, $\mathrm{y}_{9}$ 

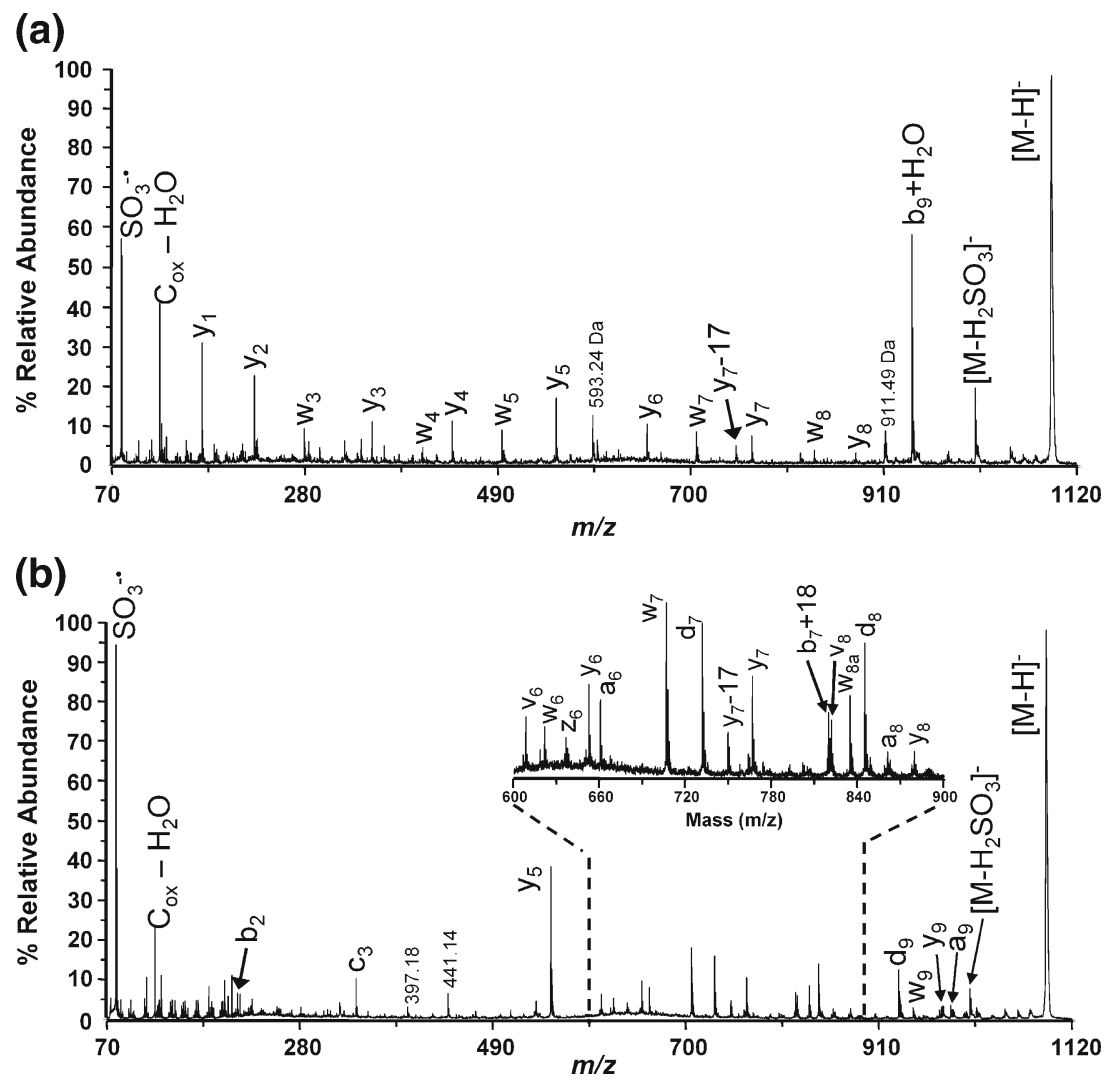

Figure 2. $1 \mathrm{keV} \mathrm{MS/MS} \mathrm{spectra} \mathrm{of}[\mathrm{M}-\mathrm{H}]^{-}$ions form (a). LVINVLSQGC ${ }_{\mathrm{ox}}$ and (b). LVINVC $\mathrm{Lx}_{\mathrm{LSQ}}$. In spectrum B the inset provides an expanded view of the $m / z$ range $780-860$ to illustrate the presence of the $\mathrm{b}_{7}+18$ fragment ion at $m / z$ 819.31

(Supplementary Material Figure S2). Cleavage of the amide bond on the C-terminal side of acidic residues under nonmobile proton conditions from protonated peptides is well established [33]. Men and Wang have noted that the efficiency for cleavage at cysteic acids is similar to that observed for aspartic and glutamic acids but considerably

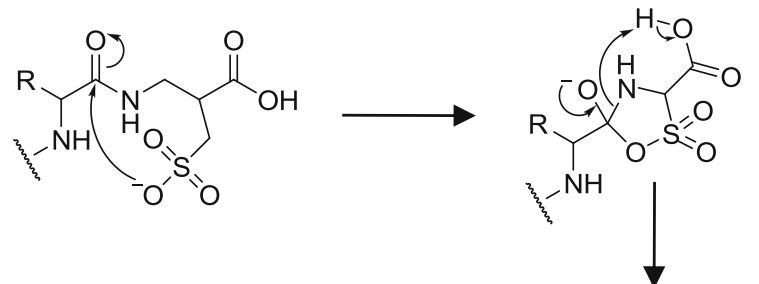<smiles></smiles>

$\mathrm{b}_{n-1}+\mathrm{H}_{2} \mathrm{O}$

Scheme 1. Proposed mechanism for the formation of the $\mathrm{b}_{n-1}+\mathrm{H}_{2} \mathrm{O}$ ion from the $\mathrm{C}$-terminal cysteic acid containing peptide less than for cysteine sulfinic acids [20]. Although the presence of both $\mathrm{b}$ and $\mathrm{y}$ ions indicates a mixed population of ions corresponding to deprotonation at either cysteic acid, the greater prevalence of $y$ ions suggests charge retention of the C-terminal may be preferred.

\section{C-terminal Basic Residue}

In bottom-up peptide sequencing approaches, tryptic digestion is extensively utilized prior to MS analysis and results primarily in peptide containing a C-terminal arginine or lysine residues. Consequently, we have considered the effect of a C-terminal lysine or arginine residue on N-terminal peptide anions. Figure 4 contains the negative fragment ion spectra of three N-terminal cysteic acid decapeptides in which the amino acids at positions 6 and 10 are varied: (A)

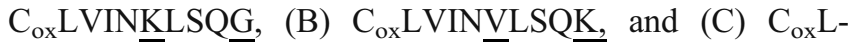
VINVLSQR. Qualitative features common to the three mass spectra are an extensive array of $\mathrm{N}$-terminal ions including: a complete series of $\mathrm{d}_{i}$ fragment ions $\left(\mathrm{d}_{2}-\mathrm{d}_{10}\right)$, extensive atype ions $\left(a_{1}, a_{3}, a_{4}, a_{5}, a_{6}\right.$, and $\left.a_{8}\right)$ and $b$-type $\left(b_{4}, b_{5}\right.$, and $\left.b_{6}\right)$ ions as well as $c_{4}$ and $c_{7}$ ions. Three fragment ions, $a_{9}, b_{9}$, and $\mathrm{b}_{9}+\mathrm{H}_{2} \mathrm{O}$ are observed in the peptides containing a $\mathrm{C}$ terminal basic residue, but the same ions are not observed when the basic residue is at position $6,\left(\mathrm{C}_{\mathrm{ox}}\right.$ LVINKLSQG). 


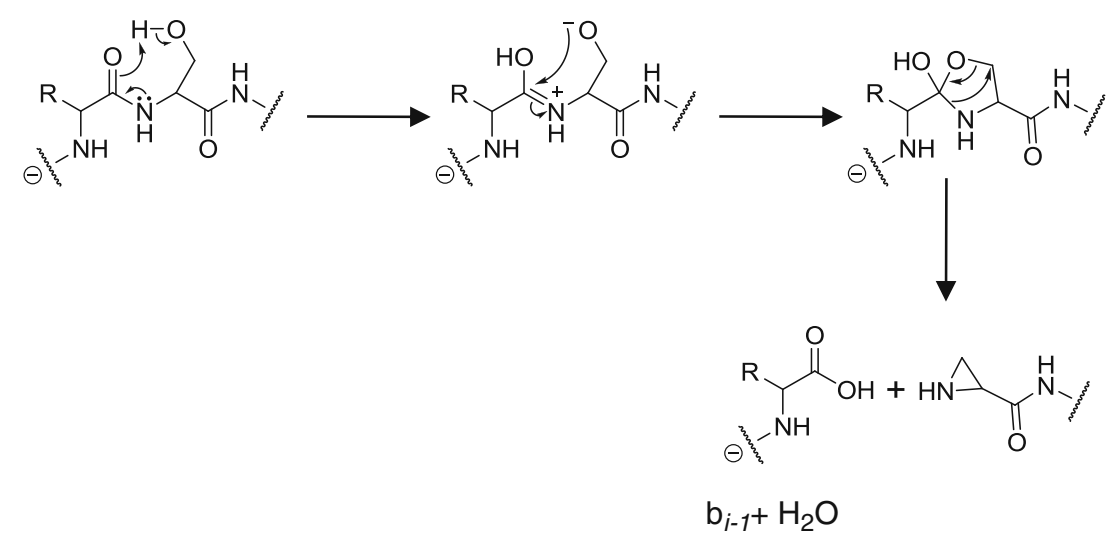

Scheme 2. Mechanism proposed by Fang and co-workers for the formation of $b+\mathrm{H}_{2} \mathrm{O}$ ions $\mathrm{N}$-terminal side of serine residues

The most prominent of these ions is the $\mathrm{b}_{9}+\mathrm{H}_{2} \mathrm{O}$ ion, which is the largest product ion peak in the dissociation spectrum of $\mathrm{C}_{\mathrm{ox}}$ LVINVLSQR and $\mathrm{C}_{\mathrm{ox}}$ LVINVLSQK. The $\mathrm{b}_{9}+\mathrm{H}_{2} \mathrm{O}$ ion corresponds to the loss of the C-terminal residue and is an example of $a b_{n-1}+\mathrm{H}_{2} \mathrm{O}$ ion, which we also observed in the dissociation of LVINVLSQGC $\mathrm{ox}_{\mathrm{ox}}$. We rationalized the formation of the $\mathrm{b}_{n-1}+\mathrm{H}_{2} \mathrm{O}$ ion from the C-terminal cysteic acid containing peptide by a charge directed pathway, however, the same mechanism is not applicable to the $\mathrm{C}$-terminal arginine and lysine containing peptides. The $\mathrm{b}_{n-1}+\mathrm{H}_{2} \mathrm{O}$ ion has been reported previously from the CID of peptide ions in both positive and negative mode [31, 34-39]. Indeed, $\mathrm{b}_{n-1}+\mathrm{H}_{2} \mathrm{O}$ is typically the principle product ions observed upon dissociation of alkali ionized peptides.

The prominence of this product ion in the CID of alkali ionized peptides has led to detailed investigation of the mechanism for fragmentation. Evidence for the mechanism of dissociation comes principally from a combined theoretical and experimental investigation of model lithiated dipeptides by Lebrilla and co-workers [37], along with a simultaneous report from Farrugia and O'Hair [38] on the dissociation of protonated isomeric dipeptides Gly-Arg and Arg-Gly. The mechanistic picture which emerges from these reports involves the formation of an oxazolidin-5-one via a salt-bridge type intermediate. Critically, this salt-bridge type mechanism involves the $\mathrm{N}$ terminal amine behaving as a proton shuttle. Initially the amine acts as a base to deprotonate the C-terminus generating a nucleophilic carboxylate, which attacks the adjacent amide carbon to form the oxazolidin-5-one framework. Following cyclization the positively charged $\mathrm{N}$-terminal ammonium acts as an acid facilitating ring opening to an anhydride intermediate which dissociates to provide the $\mathrm{b}_{n-1}+\mathrm{H}_{2} \mathrm{O}$ ion.

We propose a similar mechanism to account for the formation of the $\mathrm{b}_{n-1}+\mathrm{H}_{2} \mathrm{O}$ and $\mathrm{a}_{n-1}$ ions for the C-terminal lysine and arginine containing peptides. Scheme 3 illustrates this for the case of the lysine containing peptide. In this mechanism, the negative charge is sequestered at the cysteic acid at the N-terminus, the side chain of the $\mathrm{C}$-terminal basic residue acts as a proton shuttle, initially deprotonating the carboxylic acid. Nucleophilic attack by the carboxylate at the adjacent amide carbon followed by return of the proton from the charged side chain yields the oxazolidin-5-one intermediate, which may undergo ring opening to yield an

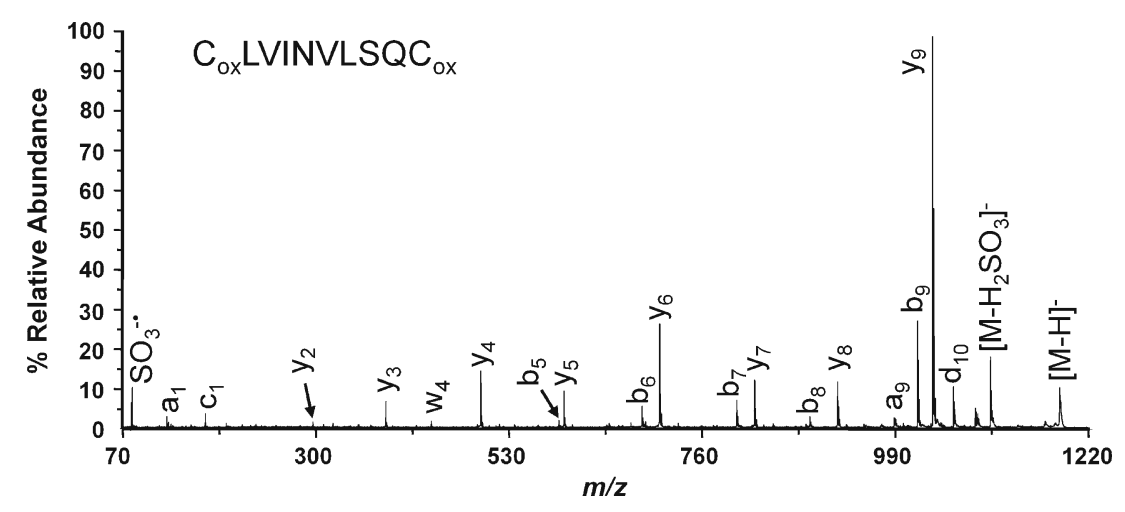

Figure 3. The negative ion tandem mass spectrum of the $[M-H]^{-}$ion for $M=C_{o x} L V I N V L S Q C_{o x}$ 


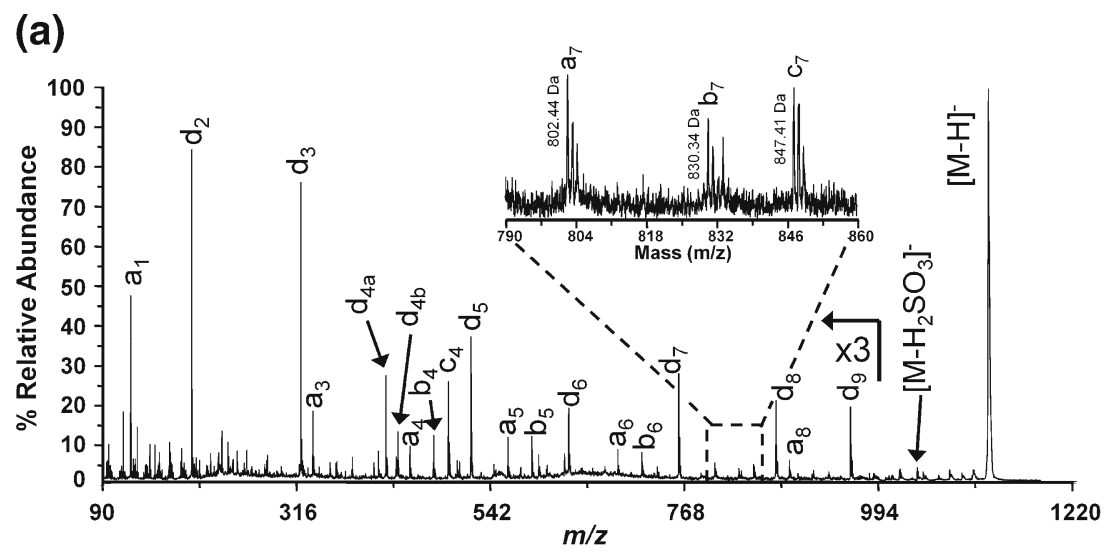

(b)

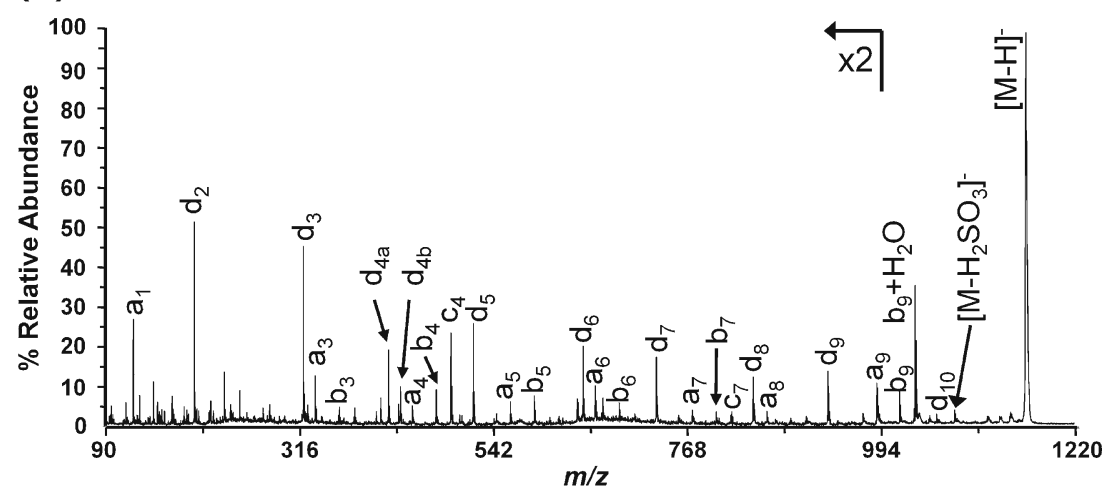

(c)

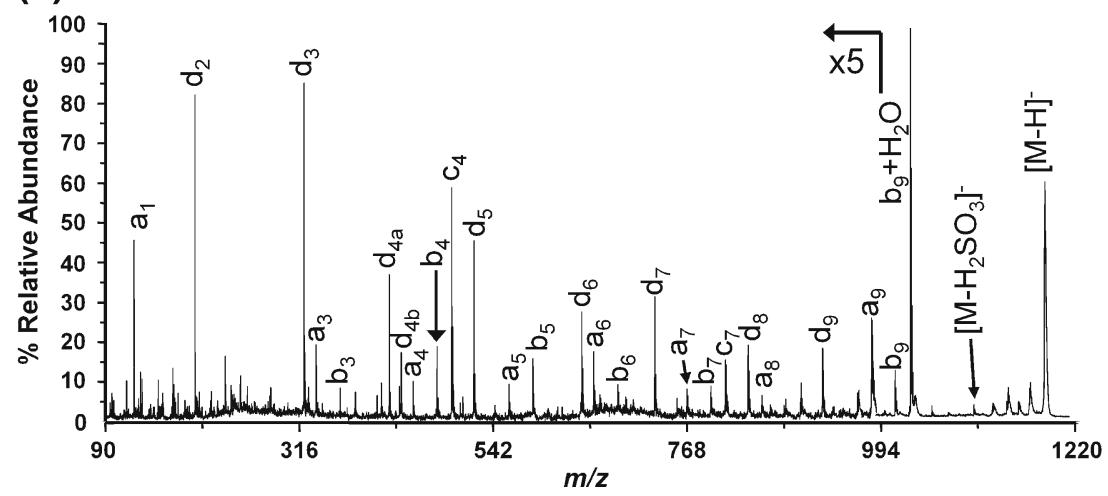

Figure 4. Negative ion tandem mass spectra of $\left[\mathrm{M}-\mathrm{H}^{-}\right.$ions from cysteic acid-containing peptides with the basic amino acid at various positions. (a) lysine in the middle ( $\mathrm{C}_{\mathrm{ox}}$ LVINKLSQG), (b) C-terminal lysine ( $\left.\mathrm{C}_{\mathrm{ox}} \mathrm{LVINVLSQK}\right)$, and (c) C-terminal arginine ( $\mathrm{C}_{\text {ox }}$ LVINVLSQR). Note that ion signals below $\mathrm{m} / z 90\left(\mathrm{SO}_{3}^{-{ }^{-}}(\mathrm{m} / \mathrm{z} 79.95)\right.$ and $\mathrm{HSO}_{3}{ }^{-}(\mathrm{m} / \mathrm{z}$ 80.96)) have been removed from both fragment ion spectra for clarity

anhydride. Cleavage of the anhydride will yield either the $\mathrm{a}_{9}$ or $\mathrm{b}_{9}+\mathrm{H}_{2} \mathrm{O}$, paths $a$ and $b$, respectively. This mechanism attributes the selective formation of $b_{9}+\mathrm{H}_{2} \mathrm{O}$ and $\mathrm{a}_{9}$ ions from the peptides containing $\mathrm{C}$-terminal basic residues to their capacity to support a zwitterionic type intermediate in which they deprotonate the carboxylic acid. Supporting this proposal is the observation that the $\mathrm{b}_{n-1}+\mathrm{H}_{2} \mathrm{O}$ ion no longer observed upon methyl esterification of the $\mathrm{C}$-terminus (Supplementary Material Figure S3). Accordingly, the greater basicity of arginine compared to lysine would account for the greater prevalence of the $\mathrm{b}_{n-1}+\mathrm{H}_{2} \mathrm{O}$ ion (relative to other sequence ions) in the CID spectra of $\mathrm{C}_{\text {ox }}$ LVINVLSQR compared with $\mathrm{C}_{\text {ox }}$ LVINVLSQK.

\section{Conclusions}

$\mathrm{SO}_{3}{ }^{-}$is a major product ion from the dissociation of deprotonated cysteic acid containing peptide anions. This 


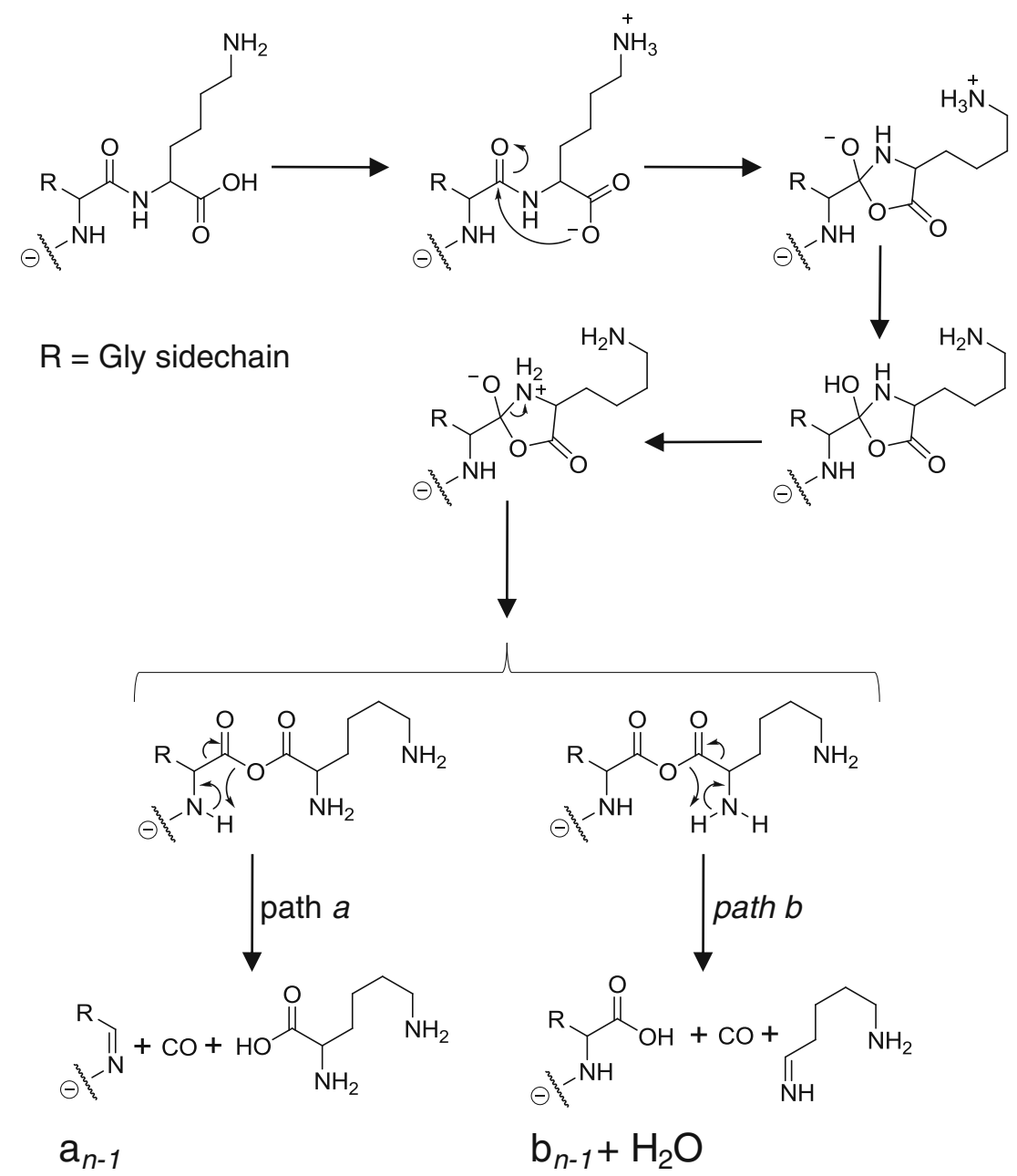

Scheme 3. Proposed mechanism to account for the formation of $\mathrm{a}_{n-1}$ and $\mathrm{b}_{n-1}+\mathrm{H}_{2} \mathrm{O}$ ions from peptides containing a C-terminal basic residue, illustrated here for the case of lysine

raises the possibility of selectively detecting cysteic acid containing peptides through the use of precursor ion scanning. In contrast to aspartic and glutamic acid containing peptide anions in which deprotonation and, hence, charge may reside at the acidic side chain or C-terminus, in cysteic acid containing peptide anions, deprotonation occurs exclusively at the cysteic acid side chain. Furthermore, charge retention appears insensitive to cysteic acid position, occurring for cysteic acid containing peptides in which the cysteic acid residue is located at the N, C, and internal positions. For example, for negative fragment ion spectrum of LVINVC $_{\text {ox }}$ LSQG a mixture of d-, v-, and w-type fragment ions form on either side of the cysteic acid. The $\mathrm{b}_{n-1}+\mathrm{H}_{2} \mathrm{O}$ product ion is observed from cysteic acid containing peptides in which the C-terminal residue corresponds to a $C_{o x}, R$, or $K$. In the $C_{o x}$ case, this loss is consistent with previous observations that this ion is formed from deprotonated peptides containing a $\mathrm{C}$-terminal acid residue. In the case of the basic residue $\mathrm{R}$ and $\mathrm{K}$, the result is rationalized by a mechanism in which the free base side chain acts as a proton shuttle.

\section{Acknowledgments}

The authors acknowledge support for this work by the Department of Energy, Division of Chemical Sciences, Offices of Basic Energy Sciences, BES DE-FG02-04ER15520.

\section{References}

1. Andersen, J.K.: Oxidative stress in neurodegeneration: cause or consequence? Nat. Med. 10(Suppl), S18-S25 (2004)

2. James, E.K., Lisa, M.K.: The role of oxdiative stress in carcinogenesis. Annu Rev. Pharmacol. Toxicol. 44, 239 (2004)

3. Lowell, B.B., Shulman, G.I.: Mitochondrial dysfunction and type 2 diabetes. Science 307, 384-387 (2005)

4. Schafer, F.Q., Buettner, G.R.: Redox environment of the cell as viewed through the redox state of the glutathione disulfide/glutathione couple. Free Radic. Biol. Med. 30, 1191-1212 (2001) 
5. Reddie, K.G., Carroll, K.S.: Expanding the functional diversity of proteins through cysteine oxidation. Curr. Opin. Chem. Biol. 12, 746754 (2008)

6. Hansen, R.E., Roth, D., Winther, J.R.: Quantifying the global cellular thiol-disulfide status. Proc. Natl. Acad. Sci. U. S. A. 106, 422-427 (2009)

7. Giorgio, M., Trinei, M., Migliaccio, E., Pelicci, P.G.: Hydrogen peroxide: a metabolic by-product or a common mediator of aging signals? Nat. Rev. Mol. Cell Biol. 8, 722-728 (2007)

8. Rhee, S.G.: Cell signaling: $\mathrm{H}_{2} \mathrm{O}_{2}$, a necessary evil for cell signaling. Science 312, 1882-1883 (2006)

9. Janssen-Heininger, Y.M.W., Mossman, B.T., Heintz, N.H., Forman, H. J., Kalyanaraman, B., Finkel, T., Stamler, J.S., Rhee, S.G., van der Vliet, A.: Redox-Based Regulation of Signal Transduction: Principles, Pitfalls, and Promises. Free Radic. Biol. Med. 45, 1-17 (2008)

10. Paulsen, C.E., Carroll, K.S.: Orchestrating redox signaling networks through regulatory cysteine switches. ACS Chem. Biol. 5, 47-62 (2009)

11. Salmeen, A., Andersen, J.N., Myers, M.P., Meng, T.-C., Hinks, J.A., Tonks, N.K., Barford, D.: Redox regulation of protein tyrosine phosphatase 1B involves a sulphenyl-amide intermediate. Nature $\mathbf{4 2 3}$ 769 (2003)

12. Hamann, M., Zhang, T., Hendrich, S., Thomas, J.A.: Quantitation of protein sulfinic and sulfonic acid, irreversibly oxidized protein cysteine sites in cellular proteins. Meth. Enzymol. 348, 146-156 (2002)

13. Biteau, B., Labarre, J., Toledano, M.B.: ATP-Dependent reduction of Cysteine-Sulphinic acid by S. cerevisiae sulphiredoxin. Nature 425, 980 (2003)

14. Tasaki, T., Kwon, Y.T.: The mammalian N-end rule pathway: new insights into its components and physiological roles. Trends Biochem. Sci. 32, 520-528 (2007)

15. Burlet, O., Yang, C.-Y., Gaskell, S.J.: Influence of cysteine to cysteic acid oxidation on the collision-activated decomposition of protonated peptides: evidence for intraionic interactions. J. Am. Soc. Mass Spectrom. 3, 337-344 (1992)

16. Cox, K.A., Gaskell, S.J., Morris, M., Whiting, A.: Role of the site of protonation in the low-energy decompositions of gas-phase peptide ions. J. Am. Soc. Mass Spectrom. 7, 522-531 (1996)

17. Summerfield, S.G., Cox, K.A., Gaskell, S.J.: The promotion of d-type ions during the low energy collision-induced dissociation of some cysteic acid-containing peptides. J. Am. Soc. Mass Spectrom. 8, 25-31 (1997)

18. Tsaprailis, G., Nair, H., Somogyi, Á., Wysocki, V.H., Zhong, W., Futrell, J.H., Summerfield, S.G., Gaskell, S.J.: Influence of secondary structure on the fragmentation of protonated peptides. J. Am. Chem. Soc. 121, 5142-5154 (1999)

19. Wang, Y., Vivekananda, S., Men, L., Zhang, Q.: Fragmentation of protonated ions of peptides containing cysteine, cysteine sulfinic acid, and cysteine sulfonic acid. J. Am. Soc. Mass Spectrom. 15, 697-702 (2004)

20. Men, L., Wang, Y.: Further studies on the fragmentation of protonated ions of peptides containing aspartic acid, glutamic acid, cysteine sulfinic acid, and cysteine sulfonic acid. Rapid Commun. Mass Spectrom. 19, 23-30 (2005)

21. Srikanth, R., Wilson, J., Bridgewater, J.D., Numbers, J.R., Lim, J., Olbris, M.R., Kettani, A., Vachet, R.W.: Improved sequencing of oxidized cysteine and methionine containing peptides using electron transfer dissociation. J. Am. Soc. Mass Spectrom. 18, 1499-1506 (2007)

22. Men, L., Wang, Y.: Fragmentation of the deprotonated ions of peptides containing cysteine, cysteine sulfinic acid, cysteine sulfonic acid, aspartic acid, and glutamic acid. Rapid Commun. Mass Spectrom. 20, 777-784 (2006)

23. Williams, B.J., Kmiec, K.L., Russell, W.K., Russell, D.H. Effect of Cysteic Acid Position on the Negative Ion Fragmentation of Proteolytic Derived Peptides. J. Am. Soc. Mass Spectrom. 2010, in press.

24. Edmondson, R.D., Russell, D.H.: Evaluation of matrix-assisted laser desorption ionization-time-of-flight mass measurement accuracy by using delayed extraction. J. Am. Soc. Mass Spectrom. 7, 995-1001 (1996)

25. Hirs, C.H.W.: Performic acid oxidation. Meth. Enzymol. 11, 197-199 (1967)

26. Williams, B.J., Russell, W.K., Russell, D.H.: High-throughput on-target performic acid oxidation method for MALDI deposited samples. $J$. Mass Spectrom. 45, 157-166 (2010)

27. Reid, G.E., Simpson, R.J., O'Hair, R.A.J.: A mass spectrometric and ab initio study of the pathways for dehydration of simple glycine and cysteine-containing peptide $[\mathrm{M}+\mathrm{H}]^{+}$ions. J. Am. Soc. Mass Spectrom. 9, 945-956 (1998)

28. Roepstorff, P., Fohlman, J.: Proposal for a common nomenclature for sequence ions in mass spectra of peptides. Biol. Mass Spectrom. 11, 601 (1984)

29. Johnson, R.S., Martin, S.A., Biemann, K.: Collision-induced fragmentation of $(\mathrm{M}+\mathrm{H})^{+}$ions of peptides. Side chain-specific sequence ions. Int. J. Mass Spectrom. Ion Processes 86, 137-154 (1988)

30. Pu, D., Cassady, C.J.: Negative ion dissociation of peptides containing hydroxyl side chains. Rapid Commun. Mass Spectrom. 22, 91-100 (2008)

31. Li, Z., Yalcin, T., Cassady, C.J.: C-terminal amino acid residue loss for deprotonated peptide ions containing glutamic acid, aspartic acid, or serine residues at the $C$-terminus. J. Mass Spectrom. 41, 939-949 (2006)

32. Fang, S., Takao, T., Satomi, Y., Mo, W., Shimonishi, Y.: Novel rearranged ions observed for protonated peptides via metastable decomposition in matrix-assisted laser desorption/ionization time-offlight mass spectrometry. J. Am. Soc. Mass Spectrom. 11, 345-351 (2000)

33. Huang, Y., Triscari, J.M., Tseng, G.C., Pasa-Tolic, L., Lipton, M.S., Smith, R.D., Wysocki, V.H.: Statistical characterization of the charge state and residue dependence of low-energy CID peptide dissociation patterns. Anal. Chem. 77, 5800-5813 (2005)

34. Thorne, G.C., Ballard, K.D., Gaskell, S.J.: Metastable decomposition of peptide $[\mathrm{M}+\mathrm{H}]^{+}$ions via rearrangement involving loss of the C-terminal amino acid residue. J. Am. Soc. Mass Spectrom. 1, 249-257 (1990)

35. Grese, R.P., Cerny, R.L., Gross, M.L.: Metal ion-peptide interactions in the gas phase: a tandem mass spectrometry study of alkali metal cationized peptides. J. Am. Chem. Soc. 111, 2835-2842 (1989)

36. Gonzalez, J., Besada, V., Garay, H., Reyes, O., Padron, G., Tambara, Y., Takao, T., Shimonishi, Y.: Effect of the position of a basic amino acid on c-terminal rearrangement of protonated peptides upon collisioninduced dissociation. J. Mass Spectrom. 31, 150-158 (1996)

37. Feng, W.Y., Gronert, S., Fletcher, K.A., Warres, A., Lebrilla, C.B.: The mechanism of C-terminal fragmentations in alkali metal ion complexes of peptides. Int. J. Mass Spectrom. 222, 117-134 (2003)

38. Farrugia, J.M., O'Hair, R.A.J.: Involvement of salt-bridges in a novel gas phase rearrangement of protonated arginine-containing peptides which precedes fragmentation. Int. J. Mass Spectrom. 222, 229-242 (2003)

39. Sadagopan, N., Watson, J.T.: Mass spectrometric evidence for mechanisms of fragmentation of charge-derivatized peptides. $J . \mathrm{Am}$. Soc. Mass Spectrom. 12, 399-409 (2001) 